\title{
ANTIOXIDANT AND ANTICHOLINESTERASE ACTIVITIES OF JUGLANS REGIA L. GROWING IN TURKEY
}

\author{
TÜRKIYYE'DE YETIŞEN JUGLANS REGIA L. 'NIN ANTIOKSIDAN VE \\ ANTIKOLINESTERAZ AKTIVITELERI
}

\section{Songül KARAKAYA ${ }^{1, *}$, Mehmet KOCA ${ }^{2}$, Fatma YEŞILYURT ${ }^{3}$, Ahmet HACIMÜFTÜOĞLU ${ }^{3}$}
${ }^{1}$ Ataturk University, Faculty of Pharmacy, Department of Pharmacognosy, Erzurum, Turkey
${ }^{2}$ Ataturk University, Faculty of Pharmacy, Department of Pharmaceutical Chemistry, Erzurum, Turkey
${ }^{3}$ Ataturk University, Faculty of Medicine, Department of Medical Pharmacology, Erzurum, Turkey

\begin{abstract}
Objective: World's ageing population continues to grow older together with high percentage prevalence of Alzheimer's disease encourage science to find herbs or biologic compounds which can be utilized for it prophylaxis. Juglans regia L. is not simply an agricultural product, its fruits, leaves, barks, stems, pericarps, and flowers are all utilized for diversified medicinal usages. In the present investigation, we examined the anticholinesterase and antioxidant capacities of the lyophilized aqueous extracts of leaves from J. regia.

Material and Method: Phenolic contents and antioxidant activity were assessed by Folin-Ciocalteu's, qualitative/quantitative DPPH and TBA methods. Anticholinesterase activity was assessed by Ellman's method.

Result and Discussion: The total phenolic content was found $478.32 \mathrm{mg} / \mathrm{g}$. The extract indicated antioxidant activity with DPPH test $\left(I_{50}: 123.66 \mu \mathrm{g} / \mathrm{mL}\right)$ and TBA assay $\left(I_{50}: 209.23 \mu \mathrm{g} / \mathrm{mL}\right)$. Moreover, the extract of $J$. regia indicated remarkable inhibition towards acetylcholinesterase (40.09\%) and butyrylcholinesyterase (56.23\%) enzymes. These data propose that J. regia can be utilised a potency for pharmaceutical products which get antioxidant and anticholinesterase activity.

Keywords: Antioxidant, Anticholinesterase, Juglans regia, Juglandaceae
\end{abstract}

\footnotetext{
* Corresponding Author / Sorumlu Yazar: Songül Karakaya e-mail: ecz-songul@hotmail.com.tr

Submitted/Gönderilme: 21.02.2019 Accepted/Kabul: 02.07.2019
} 


\section{ÖZ}

Amaç: Dünyanın yaşlanan nüfusu, Alzheimer hastalı̆̆ının yüksek oranda prevalansı ile birlikte yaşlanmaya devam etmekte ve bilimi, profilakside kullanılabilecek bitkileri veya biyolojik bileşikleri bulmaya teşvik etmektedir. Juglans regia L. basit tarımsal bir ürün değildir, meyvelerinin, yapraklarının, kabuklarının, gövdelerinin, perikarplarının ve çiçeklerinin farklı tıbbi kullanım alanları bulunmaktadır. Bu çalışmada, J. regia'nın yapraklarının liyofilize sulu ekstrelerinin antikolinesteraz ve antioksidan kapasitelerini inceledik.

Gereç ve Yöntem: Fenolik içerik ve antioksidan aktivite Folin-Ciocalteu, kalitatif/kantitatif DPPH ve TBA yöntemleri ile belirlenmiştir. Antikolinesteraz aktivite ise Ellman metodu ile değerlendirilmiştir.

Sonuç ve Tartışma: Total fenolik içerik $478.32 \mathrm{mg} / \mathrm{g}$ olarak bulunmuştur. Örnekler DPPH $(123.66 \mu \mathrm{g} / \mathrm{mL})$ ve TBA $(209.23 \mu \mathrm{g} / \mathrm{mL})$ testleri ile antioksidan aktivite göstermiştir. Ayrica, ceviz ekstresi, sırasiyla asetilkolinesteraz (\%40.09) ve butirilkolinesteraz (\%56.23) enzimlerine karşı önemli ölçüde inhibisyon göstermiştir. Bu veriler, J. regia'nın, antioksidan ve antikolinesteraz aktivitesi alan farmasötik ürünler için bir potansiyel olarak kullanabileceğini önermektedir.

Anahtar Kelimeler: Antioksidan, Antikolinesteraz, Juglans regia, Juglandaceae

\section{INTRODUCTION}

Alzheimer's disease (AD) is a degenerative brain ailment and the most extensive case of dementia. In $\mathrm{AD}$, neurons in other zones of the brain are at the end injured or slummed as much as, inclusionary those that let a human to do fundamental body functions such as walk and deglutition. The folk in the last degrees of the ailment are bed-bound and take around-the-clock care. AD is at the end lethal [1]. Many concerns could be grouped as irregular AD, where a major risk factor is an age. Wherefore the aging population, it is awaited that AD will be a hassle socio-economic difficulty in the forthcoming years [2]. Oxidative stress comes about through injury to nerves or metal conglomeration is also sorely connected to the pathogenesis of $\mathrm{AD}$, it is rather substantial to own both antioxidant and anticholinesterase potencies for a medication nominee towards AD [3].

Antioxidants could do out ROS and crack inflammatory pathways. The using of antioxidants is utility in AD progress [4]. A lot of studies have been done on the biologic effects of herbs which are exploited conventionally as memory enhancers and acetylcholinesterase [5,6].

The genus Juglans L. (Juglandaceae) includes a few species and is largely deployed around the world. Barks, green walnuts, kernels, shells, leaves, and seeds are utilized in the pharmaceutic and cosmetics industries. Leaves are smoothly present in plentiful amounts. The leaves of walnuts are thought-out to be a resource of medical service components and have been intensely utilized in folk medicine for the curation of haemorrhoids, diarrhea, venous deficiency, fungal or microbial infections and hypoglycemia [7]. Member of walnut is significant resources of nuts and woods, in the moderate districts along with the world. Juglans regia L. is not simply an agricultural product, pericarps, leaves, stems, flowers, fruits, ligneous membranes and barks of it are all utilized for diversified medical usages [8]. The walnut tree is its well-recognized member, composing a significant plant of deciduous trees grown principally in moderate regions and cultivated commercially along the United States, North Africa, western South America, southern Europe, and East Asia [9]. 
Hence, the aim of the presented research is the original search on against acetylcholinesterase (AChE) and butyrylcholinesterase (BuChE) enzymes along with antioxidant potentials of aqueous extracts from leaves of J. regia.

\section{MATERIAL AND METHOD}

\section{Plant material}

The plant was collected by authors from Şenyurt village, Tortum, Erzurum (Turkey) in May 2018. Voucher examples are stored in AUEF (Herbarium of Atatürk University Faculty of Pharmacy) (AUEF 1362).

\section{Chemicals}

Methanol (Merck), Dichloromethane (Merck), Ethyl acetate (Merck), n-Buthanol (Merck), Folin-Ciocalteu reagent (Molychem 31740), Gallic acid (Riedel de Haen), Phosphate buffer (Biomatik A3602), DPPH $^{\circ}$ reagent (Sigma, 84077-81-6), Ferric chloride (Sigma 7705-08-0), Thiobarbituric acid (SigmaAldrich T5500), Ascorbic acid (SigmaAldrich A1300000), Brain extract (B3635), Butylated hydroxytoluene (Sigma-Aldrich B1378), Rutin (R5143), Proply gallate (P5,330-6), Chlorogenic acid (C3878), TLC plates (Merck), TRIZMA HCL (Sigma T5941-500G), Magnesıum Chloride Hexahydrate (Sigma M2670-100G), Sodium Chloride (Isolab 969.036.1000), 5,5-Dithio-B1s(2-Nitrobenzoic Acid) (Sigma D8130-5G), Acetylthiocholine Iodide (Sigma A5751-5G), S-Butyrylthiocholine Iodide Crystalline (Sigma B3253-5G), Albumin Bovine Fraction V Powder (Sigma A2153-10G), Cholinesterase, Acetyl Type V1-S Fromele (Sigma C3389-500UN).

\section{Preparation of extract}

$50 \mathrm{~g}$ of leaves of Juglans regia were grounded and macerated with $300 \mathrm{~mL}$ of distilled water for $8 \mathrm{~h} / 3$ days at 30 to $35^{\circ} \mathrm{C}$. The aqueous extract was filtered, frozen (Sanyo Medical Freezer, Germany) and lyophilized (Christ ${ }^{\circledR}$ Gamma 2-16 LSC, Germany) to give an aqueous extract of leaves. $5.78 \mathrm{~g}$ of extract was obtained.

\section{Total phenolic content}

The total polyphenol content of the extract was done referring to Karakaya et al., 2018 [10]. The procedure was recapped 3 times.

\section{Antioxidant activity}

\section{Qualitative DPPH}

The qualitative DPPH of the extract was done referring to Karakaya et al., 2018 [10]. The procedure was recapped 3 times. 


\section{Quantitative DPPH}

The quantitative DPPH of the extract was done referring to Karakaya et al., 2018 [10]. The IC $_{50}$ values of examples were specified through linear regression analysis and testings were carried out in triplicate. In seven concentrations: $10 \mathrm{mg} / \mathrm{mL}, 5 \mathrm{mg} / \mathrm{mL}, 2.5 \mathrm{mg} / \mathrm{mL}, 1.25 \mathrm{mg} / \mathrm{mL}, 0.625 \mathrm{mg} / \mathrm{mL}, 0.3125$ $\mathrm{mg} / \mathrm{mL}, 0.15625 \mathrm{mg} / \mathrm{mL}$ were done.

\section{Anti-lipid peroxidation activity}

The anti-lipid peroxidation activity of the extract was done referring to Karakaya et al., 2018 [10]. The $\mathrm{IC}_{50}$ values were assessed through linear regression analysis. Seven varied concentrations (0.016-1 $\mathrm{mg} / \mathrm{mL}$ ) of examples were studied in this analysis. Chlorogenic acid, rutin, and propyl gallate were prepared as reference compounds in seven varied concentrations $(0.000064-1 \mathrm{mg} / \mathrm{mL})$, and chlorogenic acid and rutin were utilized in the same concentration interval.

\section{Detection of $\mathrm{AChE}$ and $\mathrm{BuChE}$ inhibition activities}

The detection of $\mathrm{AChE}$ and $\mathrm{BuChE}$ inhibition activities of the extract was done referring to Karakaya et al., 2018 [10]. This procedure was recapped 3 times. Entire data were remarked as mean \pm SE of 3 independent testings. $25 \mu \mathrm{L}$ of varied four concentrations of the inhibitor extract (20, 10,5 and $2.5 \mu \mathrm{g} / \mathrm{mL}$ ) were studied.

\section{Statistical analysis}

Entire data are specified as mean $\pm \mathrm{SE}$ and changes were statistically analysed by way of ANOVA one-way analysis dogged by way of complementary analysis of Bonferroni $(\mathrm{P}<0.05)$, conceived to indicated statistic relevance.

\section{RESULT AND DISCUSSION}

The extract of Juglans regia was studied regarding antioxidant capacity potential. The data of the sample regarding the content of total phenolics are presented in Table 1.

Table 1. Total phenolic contents of the leaves lyophilized aqueous extract from Juglans regia.

\begin{tabular}{lc}
\hline Tested example & Total phenolic contents $(\mathrm{mg} / \mathrm{g}) \pm \mathrm{SD}^{*}$ \\
\hline Aqueous lyophilized extracts & $478.32 \pm 2.09$ \\
\hline *Standard deviation &
\end{tabular}

The total phenolic content was found $478.32 \mathrm{mg} / \mathrm{g}$. Quantitative DPPH analysis results were presented as $\mathrm{IC}_{50}$ values $(\mu \mathrm{g} / \mathrm{mL})$ in Table 2. 
Table 2. DPPH radical scavenging activity of lyophilized aqueous extract of leaves from Juglans regia $(\mu \mathrm{g} / \mathrm{mL})$.

\begin{tabular}{cc}
\hline Tested examples & $\mathrm{IC}_{50}$ values $(\mu \mathrm{g} / \mathrm{mL}) \pm \mathrm{SD}^{*}$ \\
\hline Aqueous lyophilized extracts & $123.66 \pm 2.90$ \\
Chlorogenic acid & $2.41 \pm 0.58$ \\
Propyl gallate & $0.005 \pm 0.21$ \\
Rutin & $3.05 \pm 0.89$ \\
\hline
\end{tabular}

*Standard deviation

Besides, J. regia extract showed the radical scavenging effect when compared the references chlorogenic acid, rutin, and propyl gallate. The sample indicated antioxidant activity with DPPH test and TBA methods (123.66 and $209.23 \mu \mathrm{g} / \mathrm{mL}$, respectively). The findings of TBA assay from examples were presented as $\mathrm{IC}_{50}$ values $(\mu \mathrm{g} / \mathrm{mL})$ in Table 3 .

Table 3. Antioxidant activities of lyophilized aqueous extract of leaves from Juglans regia in the TBA test.

\begin{tabular}{lc}
\hline \multicolumn{1}{c}{ Tested examples } & $\mathrm{IC}_{50}$ values $(\mu \mathrm{g} / \mathrm{mL}) \pm \mathrm{SD}^{*}$ \\
\hline Aqueous lyophilized extracts & $209.23 \pm 1.92$ \\
Chlorogenic acid & $12.98 \pm 4.89$ \\
Propyl gallate & $3.44 \pm 2.05$ \\
Rutin & $9.65 \pm 3.09$ \\
\hline
\end{tabular}

*Standard deviation

$J$. regia presented antioxidant activity on liposome in comparison to the chlorogenic acid and rutin. A correl between total phenol content, DPPH, and TBA assay analysis was gained.

Anticholinesterase potential of the extract was revealed by way of colorimetric Ellman's method [11], within a few alternations through commercially existing donepezil as a reference [12]. In vitro acetylcholinesterase of specimens at $100 \mu \mathrm{g} / \mathrm{mL}$ were represented in Table 4 .

Depends on enzyme inhibition data J. regia demonstrated remarkable stoppage activities towards to acetylcholinesterase and butyrylcholinesterase, it has been indicated substantial inhibition against $\mathrm{AChE}(40.09 \pm 2.99 \%)$ and $\mathrm{BuChE}(56.23 \pm 1.77 \%)$ at $100 \mathrm{mg} / \mathrm{mL}$. 
Table 4. In vitro AChE and BuChE inhibitory activities of lyophilized aqueous extract of leaves from Juglans regia at $100 \mu \mathrm{g} / \mathrm{mL}$.

\begin{tabular}{ccc}
\hline Tested examples & Enzyme kind & Percentile of inhibition \pm S.E.M ${ }^{\mathrm{a}}$ against AChE and BuChE \\
\hline Aqueous & $\mathrm{AChE}$ & $40.09 \pm 2.99$ \\
lyophilized & $\mathrm{BuChE}$ & $56.23 \pm 1.77$ \\
extracts & & \\
Donepezil & $\mathrm{AChE}$ & $100.0 \pm 0.99$ \\
& $\mathrm{BuChE}$ & $99.12 \pm 1.17$ \\
\hline
\end{tabular}

${ }^{\mathrm{a}}$ Standard error of the mean

J. regia extract has been characterized by a remarkable high content of total phenolics. Previously, antioxidant activities of the leaves extracts of $J$. regia were studied and it was found that walnut leaves cultivars presented strong antioxidant capacity $\left(\mathrm{EC}_{50}<1 \mathrm{mg} / \mathrm{mL}\right)$ [13]; another study indicated that leaf extract had antioxidant activity with DPPH scavenging test ( $\left.\mathrm{EC}_{50}: 0.143 \mathrm{mg} / \mathrm{mL}\right)$ [9]. Previous studies were performed on the antioxidant activity of a leaf extract from J. regia [14-16].

It was determined a remarkable correl between antioxidant capacity and content of total phenolics in previous explorations [17,18] as well. Previous studies showed that J. regia extracts scavenged DPPH radical in variable degrees; but, they did not scavenge DPMD and $\mathrm{H}_{2} \mathrm{O}_{2}$. The dichloromethane and water extracts were only able to put out SO $(10.09 \pm 1.38 \%)$ and NO (24.09 \pm $2.19 \%$ ) radicals, in order of, at low level. The extracts indicated either low or no $\mathrm{BChE}$ inhibition and no AChE inhibition [19]. Another study displayed that methanolic extract of J. regia was able to inhibit and defibrillize fibrillar amyloid $\beta$ - protein. Likewise, it was reported that two of its main components in the plant, gallic and ellagic acid, play as "dual-inhibitors" of the enzyme acetylcholinesterase. These findings recommend that this plant may reduce the risk or delay the onset of $\mathrm{AD} \mathrm{[20].}$

Alzheimer, a neurodegenerative ailment caused by oxidative stress, is a cholinergic impairment in the brain. Exclusively, an impairment in the acetylcholine summation released from cholinergic synapses has been qualified. A method of healing has been advanced to augment or remain the sum of acetylcholine through inhibiting acetylcholinesterase.

This search represented that the $J$. regia extract has inhibitory activity on AChE and BuChE along with antioxidant potential.

Most principally, Juglans regia had markable antioxidant and anticholinesterase activities. Thereof, we could conclude that J. regia can make use of in AD and can utilise a plantal alternating to synthetic medicaments which should be further certificated. 


\section{REFERENCES}

1. Alzheimer's Association. Alzheimer's disease facts and figures. Alzheimer's \& Dementia 2018, $14,367-429$.

2. Karch, S., Broichhagen, J., Schneider, J., Böning, D., Hartmann, S., Schmid, B., Tripa, P., Palmisano, R., Alzheimer, C., Johnsson, K., Huth, T (2018). A new fluorogenic small-molecule labeling tool for surface diffusion analysis and advanced fluorescence imaging of $\beta$-site amyloid precursor protein-cleaving enzyme 1 based on silicone rhodamine: SiR-BACE1. J Med Chem, $61,6121-6139$.

3. Ustun, O., Senol, F.S., Kurkcuoglu, M., Orhan, I.E., Kartal, M., Baser, K.H.C (2012). Investigation on chemical composition, anticholinesterase and antioxidant activities of extracts and essential oils of Turkish Pinus species and pycnogenol. Industrial Crops and Products, 38, 15-123.

4. Ferreira, A., Proenc, C., Serralheiro, M.L.M., Araujo, M.E.M (2006). The in vitro screening for acetylcholinesterase inhibition and antioxidant activity of medicinal plants from Portugal. J Ethnopharmacol, 108, 3-37.

5. Luz, D.A., Pinheiro, A.M., Silva, M.L., Monteiroa, M.C., Prediger, R.D., Maiaa, C.S.F., Andrad, E, Júniora, F (2016). Ethnobotany, phytochemistry and neuropharmacological effects of Petiveria alliacea L. (Phytolaccaceae): A review. J Ethnopharmacol, 185, $182-201$.

6. Perry, E.K., Pickering, A.T., Wang, W.W., Houghton, P, Perry, N.L (1998). Medicinal Plants and Alzheimer's Disease: Integrating Ethnobotanical and Contemporary Scientific Evidence. The Journal of Alternative and Complementary Medicine, 4, 419428.

7. Sharafati-Chaleshtori, R., Sharafati-Chaleshtori F., Rafieian, M (2011). Biological characterization of Iranian walnut (Juglans regia) leaves. Turk J Biol, 35, 635-639.

8. Zhang, Z., Liao, L., Moore, J., Wua, T., Wang, Z (2009). Antioxidant phenolic compounds from walnut kernels (Juglans regia L.). Food Chemistry, 113(1), 160-165.

9. Carvalho, M., Ferreira, P.J., Mendes, V.S., Silva, R., Pereira, J.A., Jerónimo, C., Silva, B.M (2010). Human cancer cell antiproliferative and antioxidant activities of Juglans regia L. Food and Chemical Toxicology, 48(1), 441-447. 
10. Karakaya, S, Koca, M, Kilic, C.S., Coskun, M (2018). Antioxidant and anticholinesterase activities of Ferulago syriaca Boiss. and F. isaurica Peșmen growing in Turkey. Med Chem Res, 27, 1843-1850.

11. Ellman, G.L., Courtney, K.D., Andresjr, V., Featherstone, R.M (1961). A new and rapid colorimetric determination of acetylcholinesterase activity. Biochem Pharmacol, 7, 8895.

12. Yerdelen, K.Ö., Tosun, A (2015). Synthesis, docking and biological evaluation of oxamide and fumaramide analogs as potential $\mathrm{AChE}$ and $\mathrm{BuChE}$ inhibitors. Med Chem Res, 24, 588-602.

13. Pereira, J.A., Oliveira, I, Sousa, A., Valentao, P., Andrade, P.B., Ferreira, I.C.F.R., Ferreres, F., Bento, A., Seabra, R., Estevinho, L (2007). Walnut (Juglans regia L.) leaves: Phenolic compounds, antibacterial activity and antioxidant potential of different cultivars. Food and Chemical Toxicology, 45, 2287-2295.

14. Almeida, I.F., Fernandes, E., Lima, J.L.F.C., Costa, P.C., Bahia, M.F (2008). Walnut (Juglans regia) leaf extracts are strong scavengers of pro-oxidant reactive species. Food Chemistry, 106, 1014-1020.

15. Amaral, J.S., Seabra, R.M., Andrade, P.B., Valentao, P., Pereira, J.A., Ferreres, F (2004). Phenolic profile in the quality control of walnut (Juglans regia L.) leaves. Food Chemistry, 88, 373-379.

16. Santos, A., Barros, L., Calhelhaa, R.C., Duenas, M., Carvalho, A.M., Santos-Buelga, C., Ferreira, I.C.F.R (2013). Leaves and decoction of Juglans regia L.: Different performances regarding bioactive compounds and in vitro antioxidant and antitumor effects. Industrial Crops and Products, 51, 430-436.

17. Sytar, O., Bruckova, K., Hunkova, E., Zivcak, M., Kiessoun, K., Brestic, M (2015). The application of Muliplex flourimetric sensor for analysis flavonoids content in the medical herbs family Asteraceae, Lamiaceae, Rosaceae. Biological research, 48(5): DOI: $10.1186 / 0717-6287-48-5$.

18. Granato, D., Shahidi, F., Wrolstad, R., Kilmartin, P., Melton, L.D., Hidalgo, F.J., Miyashita, K., Camp, J., Alasalvar, C., Ismail, A.B., Elmore, S., Birch, G.G., Charalampopoulos, D., Astley, S.B., Pegg, R., Zhou, P., Finglas, P (2018). Antioxidant activity, total phenolics and flavonoids contents: Should we ban in vitro screening methods? Food Chemistry, 264, 471-475. 
19. Erdogan, O.I., Suntar, I.P., Akkol, E.K (2011). In vitro neuroprotective effects of the leaf and fruit extracts of Juglans regia L. (walnut) through enzymes linked to Alzheimer's disease and antioxidant activity. International Journal of Food Sciences and Nutrition, 62(8), 781-786.

20. Taha, N.A., Al-wadaan, M.A (2011). Utility and importance of walnut, Juglans regia Linn: A review. African Journal of Microbiology Research, 5(32), 5796-5805. 